\title{
Fiscal Policy Reforms and Their Effects on the Economic Viability of Mineral Projects in Ghana
}

\author{
Peter Arroja Eshun ${ }^{1}$ \\ ${ }^{1}$ Mining Engineering Department, University of Mines and Technology, Tarkwa, Ghana \\ Correspondence: Peter Arroja Eshun, Mining Engineering Department, University of Mines and Technology, P. \\ O. Box 237, Tarkwa, Ghana. Tel: 233-244-658-670. E-mail: paeshun@umat.edu.gh
}

Received: May 24, 2018

Accepted: June 22, 2018

Online Published: July 5, 2018

doi:10.5539/ijef.v10n8p64

URL: https://doi.org/10.5539/ijef.v10n8p64

\begin{abstract}
Mineral sector regulatory and fiscal policies in Ghana have undergone a lot of reforms over the past three decades in an effort to attract the much-needed Foreign Direct Investment (FDI) into the mineral sector and also to maximise the returns from the exploitation of mineral asset to the country. This paper puts in perspective the effect of changes in fiscal policies on the viability of mineral projects and assesses the general risk associated with investing in the mineral industry of Ghana, using the Sikaman Gold Mining (SGM) Project as a test case. Cash flow, sensitivity and risk analyses of the SGM Project under three fiscal regimes namely: PNDCL 153, Act 703, and amendments to Act 703, indicated the second regime as the most economically favourable as it gave the highest NPV and lowest risk. It is recommended that the government should involve the mineral industry players during such reviews to show all-inclusiveness. Furthermore, mineral investors are advised to explore stability and development agreements to protect their investments in the wake of changes in fiscal policies in the mineral industry of Ghana. Future research could consider comparing the current fiscal regime of Ghana with those of the competing countries within the Sub-Saharan African region to assess whether Ghana could continue to pride itself as a preferred investment destination within the sub-region.
\end{abstract}

Keywords: fiscal policies, corporate tax, royalty, capital allowance, loss carry forward, economic evaluation

\section{Introduction}

Ghana, formerly known as the Gold Coast, currently ranks second after South Africa as the largest gold producer in Africa (Focus Economics, 2018). Mineral sector regulatory and fiscal policies in the country have undergone a lot of reforms over the years. For the past three decades, Ghana has either replaced its mining laws or made several major amendments, all in an effort to attract the much-needed foreign direct investment into the mineral sector and also to have its quota from the exploitation of its mineral asset for the development of the country.

However, critics including policymakers, non-governmental agencies, trade unions and the general public have argued that the nation is not getting enough from its mineral resources in the area of government revenue (Agbesi, 2007; Amponsah-Tawiah \& Dartey-Baah, 2011; Antwi-Boasiako, 2003; Appiah \& Buaben, 2012; Awudi, 2002; Liu, 2012). On the contrary, industry players spearheaded by the Ghana Chamber of Mines have also put forth the argument that the increment in taxes discourage investment and the expansion of ongoing projects and thus some authors have advocated for other strategies to harness benefits from the mineral industry apart from taxes (Andrews-Speed \& Rogers, 1999; Aryee, 2001; 2012; Smith, 2015; Songhai Advisory, 2011; Yirenkyi, 2008). This presents a dichotomous situation and can increase the risk of investing in the mineral sector of the country if not well handled. The import of this paper, therefore, is to give an academic insight on the effect of the changes in the fiscal policies of the country on mineral investments as a contribution to the discussion.

The paper is set out to study the fiscal policies governing the mineral investment climate of Ghana under three distinct policy regimes that reflect the three political dispensations for the past three decades: Minerals and Mining Law, 1986 (PNDC Law 153); Minerals and Mining Act 2006 (Act 703); and the revisions made to the Minerals and Mining Act 2006.

The paper utilises the various fiscal policies governing mining royalties, taxes and allowances within the three regimes to prepare cash flows and conduct sensitivity and risk analyses to assess the viability and risk associated 
with the Sikaman Gold Mining (SGM) Project as a case study. Through this approach, the impact of changes in fiscal mineral policies on the viability of mineral projects in Ghana and generally the risk associated with investing in the mineral industry of Ghana could be pragmatically assessed.

\subsection{Mineral Policy Reforms in Ghana in the Past Three Decades}

The three distinct mineral policy reforms in Ghana for the past three decades reflect the three political dispensations in the country. After independence in 1957, foreign control of the mineral sector was tampered with by increased government involvement (Akabzaa \& Darimani, 2001; Clark, 1994; Gbireh, Cobblah, \& Suglo, 2007; Tsikata, 1997). Gold production began to decline in the late 1960s into the 1970s and early 1980s amid military takeovers of governance (see Figure 1). During the period, many mines began to hit poorer gold reefs, few investors were willing to invest due to investor uncertainty about the safety of their investment, and the government failed to provide the capital necessary to expand production as a result of general decline in the economy (Clark, 1994). The mining industry got rejuvenated after the adoption of reforms that enhanced the sector's appeal to investors from 1986 after the enactment of the Minerals and Mining Law, 1986, PNDCL 153 under the Provisional National Defence Council (PNCL) government led by His Excellency Flight Lieutenant Jerry John Rawlings.

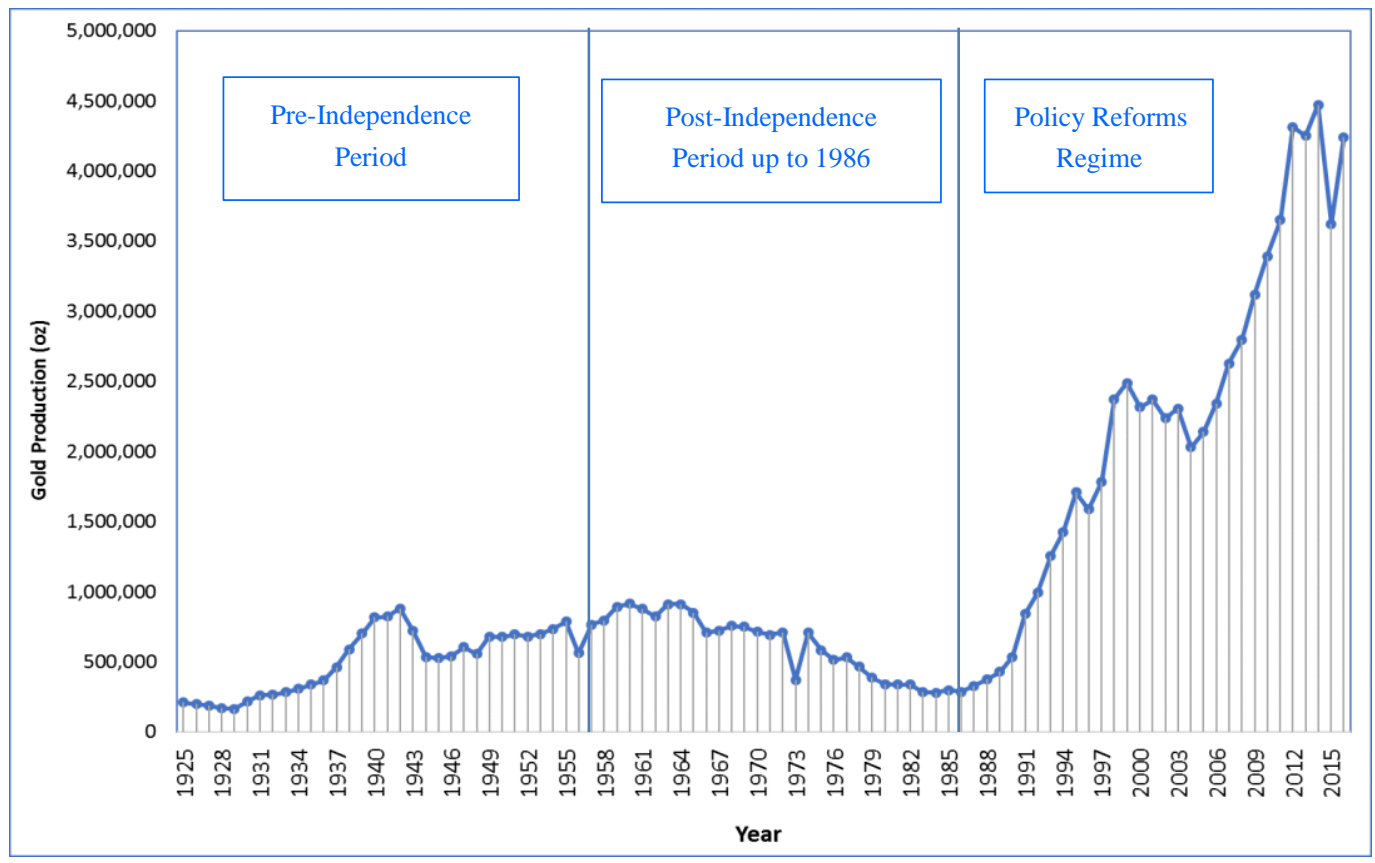

Figure 1. Gold production trend in Ghana

Note. Modified after: Kesse, 1985; Minerals Commission of Ghana.

The significance of the liberalisation in the Minerals and Mining Law, 1986, PNDCL 153 were the scaling down of corporate income tax liability and provision of more specific fiscal allowances with the aim to reduce the general tax liability of mineral investors. Corporate income tax was reduced from 50-55\% in 1975, to $45 \%$ in 1986 and further scaled down to 35\% in 1994. Initial capital allowance which enabled mineral investors to recoup their capital expenditure was increased from $20 \%$ in the first year of production and $15 \%$ for subsequent annual allowances in 1975 to $75 \%$ in first year of operation and 50\% for subsequent annual allowances in 1986. Furthermore, financial losses less than capital allowance (depreciation) for the year were to be carried forward. The royalty rate of $6 \%$ of the total value of minerals won in 1975, was reduced to a lower bound of $3 \%$ in 1987 (Songsore, Yankson, \& Tsikata, 1994).

Other duties such as mineral duty (5\%), import duty $(5-35 \%)$ and foreign exchange tax (33-75\%) that prevailed and contributed significantly to government revenue from the sector until the reforms were all scrapped (Akabzaa \& Darimani, 2001). In addition to these, mining companies were exempted from payment of customs import duties on plant, machinery equipment and accessories imported for use in mining. Their staff were also exempted from payment of income tax related to furnished accommodation at the mine site. Personal remittance quota for 
expatriate personnel was freed from any tax imposed for the transfer of external currency out of the country. Apart from these, a holder of a mining lease was permitted by the Bank of Ghana to retain a minimum of $25 \%$ of the operators' foreign exchange earnings in an external account for the purpose of acquiring equipment, spare parts, raw materials and for dividend payment and remittance in respect of goods for expatriate personnel, among others (Awudi, 2002). The enactment of the Minerals and Mining Law, 1986, PNDCL 153 was regarded as a trailblazer in terms of mining legislation in sub-Saharan Africa (Hinde, 2010) and Ghana could pride itself as preferred destination for mineral investment.

Figure 2 shows that the revitalisation of the mineral industry through the reforms yielded a positive average growth rate of $18.9 \%$ in gold production from 1986 to 1999 although average growth of gold price was negative $1.6 \%$ within the period. But, between 2000 and 2005 there was negative average growth in gold production of 2.3\% although there was positive average growth in gold price of $10.5 \%$ within the same period. The New Patriotic Party (NPP) government at the helms of leadership of the country (2001-2008) responded to the decline in gold production in the wake of increasing gold price by further making the fiscal policies more favourable to mineral investors.

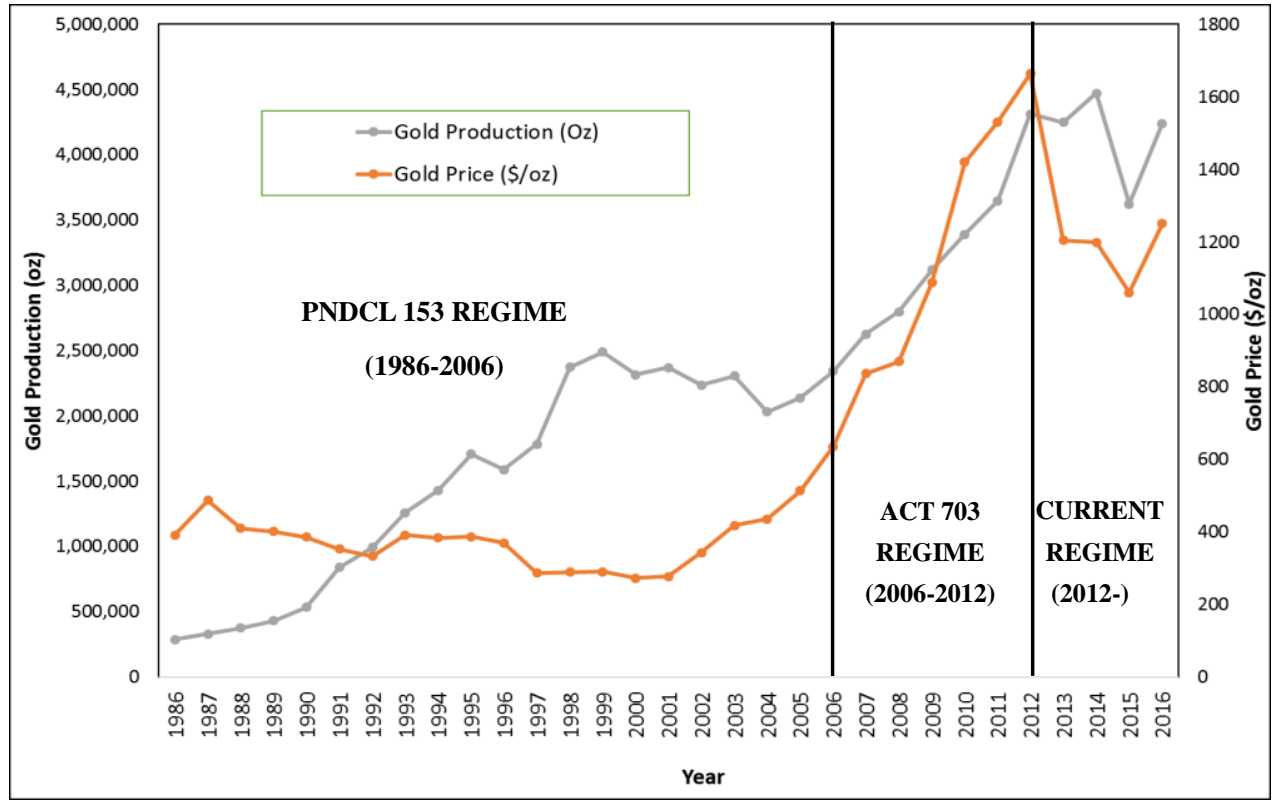

Figure 2. Gold production and price trend through different mineral policy regimes

Note. Modified after: Minerals Commission of Ghana; World Gold Council, 2017.

Thus, on December 15, 2005, the Ghanaian Parliament passed into law a new minerals and mining bill. The Minerals and Mining Act 2006 (Act 703) was enacted to further liberalise the fiscal regime by reducing the corporate income tax from $35 \%$ to $25 \%$, royalty rate from 3 - $12 \%$ (depending on the operating ratio i.e. (revenue operating cost)/revenue)) to $3-6 \%$, and scraped the additional profit tax, all in an effort to attract investment into the sector. From Figure 2, the institution of the Minerals and Mining Act 2006, Act 703 resulted in an increased average growth in gold production by $11 \%$ in the face of increased average growth in gold price by $18 \%$ from 2006 to 2012. The New Democratic Congress (NDC) government in power (2009-2016) then led by the late President Evans Fiifi Atta-Mills responded to the positive wave of increased gold price and increased production by adjusting the fiscal mineral policies upward for the nation to benefit from the mineral industry.

The amendment of the royalty rate in 2010 to a standard 5\% of the gross revenue, the 2012 increment in the corporate tax from $25 \%$ to $35 \%$, and the re-introduction of windfall tax of $10 \%$ received mixed reactions from civil societies and industry players. The then Chief Executive Officer of the Chamber of Mines, Dr Anthony Aubynn, on the one hand was quoted by Reuters warning that "this stance will likely discourage investment and the expansion of current projects" (Songhai Advisory, 2011). The Executive Secretary of the Ghana Mine Workers Union on the other hand reiterated that "the government should be bold to put its feet on the ground to maximise returns from the mineral industry" (Liu, 2012). This presented a dichotomous situation, which prompted this paper to put in perspective the changes in the fiscal policies on the viability of mineral projects in the country. This paper 
is therefore a neutral academic work to give an opinion on the dissenting views the public hold on the latest changes made to the mineral fiscal policies of the country.

The paper considers three fiscal policy regimes for the past three decades: PNDCL 153 of 1986; Act 703 of 2006; and the current amendments to Act 703. The salient fiscal policies within the three regimes that are pertinent to the economic evaluation of mineral projects in Ghana are tabulated in Table 1. It includes the fiscal policies before the enactment of PNDCL 153 to show the significance of the liberalisation in 1986. It should be noted that the windfall tax of $10 \%$ proposed under the current regime has still not been enforced by Parliament.

Table 1. Fiscal parameters pertinent to the economic evaluation of mineral projects

\begin{tabular}{lcccc}
\hline & SMCD 5 1975 & DCL 153 Regime & Act 703 Regime & Current Regime \\
\hline Corporate Income Tax & $50-55 \%$ & $35 \%$ & $25 \%$ & $35 \%$ \\
Royalty & $6 \%$ & $3-12 \%$ & $3-6 \%$ & $5 \%$ \\
Investment Allowance & $5 \%$ & $5 \%$ & $5 \%$ & N/A \\
Capital Allowance & $20 \%$ initial; $15 \%$ & $75 \%$ initial; 50\% & $75 \%$ initial; 50\% & $20 \%$ for 5 yrs \\
& subsequent yrs & subsequent yrs & subsequent yrs & \\
Additional Profit Tax/Windfall Tax & N/A & $25 \%$ & N/A & $10 \%$ (N/A) \\
\hline
\end{tabular}

Note. Modified after: Akabzaa and Darimani, 2001.

\subsection{Cushioning against Fiscal Policy Changes Using Stability and Development Agreements}

Mineral investors are able to protect their investment from changes in the fiscal policies through stability and development agreements as enshrined in Sections 48 and 49 of the Minerals and Mining Act 2006 (Act 703).

A stability agreement requires that existing laws and fiscal imposts (taxes) applicable to a mining project may be stabilised or frozen for up to fifteen years to protect a mining lease holder from adverse effects of new laws or imposts.

A development agreement is an opportunity for a mining lease holder to negotiate stability and other terms in exchange for a significant level of investment: i.e. investments exceeding US\$500 million. Typically, more favourable fiscal terms are granted under a development agreement, which are stabilised for the duration of the mining lease. Thus, while any mining lease holder may be granted a stability agreement, only holders who propose and show evidence of capacity to invest over US\$500 million are considered for a development agreement.

\section{Materials and Methods}

Data was obtained from the feasibility report of Sikaman Gold Mining Project (name modified for confidentiality) and MS Excel software was used in the data analysis. Detailed method of estimation was employed in the capital cost, operating cost and revenue estimation. Discounted cash flow analysis was used to evaluate the economic viability of the project under the three fiscal policy regimes in Ghana. Additionally, sensitivity analysis was conducted to assess the level of independent changes in the economic parameters that the project could absorb and still be economically viable. Finally, risk analysis using Monte Carlo simulation was conducted to investigate the effect of simultaneous changes in the economic parameters on the viability of the project for the three fiscal policy regimes. The discounted cash flow method is used to evaluate the economic viability of mineral projects in Ghana because of its simplicity and wider acceptability (Ampofo, 2017; Banson \& Eshun, 2010; Bhappu \& Guzman, 1995; Cobblah, 2005; Eshun \& Mireku-Gyimah, 2004; Mirakovski, Krstev, Krstev, \& Petrovski, 2009; Mireku-Gyimah \& Darko, 1996; Mireku-Gyimah \& Owusu-Ansah, 2017). The fiscal parameters pertinent to the economic evaluation of mineral projects presented in Table 1 were employed in the analyses.

\subsection{Economic Parameters for Evaluating the Viability of the SGM Project}

Detailed cost estimation methods were employed in the capital and operating cost estimates and the summary results are presented in Tables 2 and 3 respectively. The following estimates and basic assumptions were employed in the economic evaluation of the Sikaman Gold Mining Project: 
Table 2. Summary of capital cost estimates

\begin{tabular}{lc}
\hline Cost Centre & Amount (US\$ x 10 \\
\hline Pre-production Costs & \\
$\quad$ Acquisition, Exploration and Consultancy & 3000 \\
Subtotal & 3000 \\
Direct Capital Costs & 9375 \\
$\quad$ Mining & 28470 \\
Processing Plant & 2045 \\
Plant Treatment Services & 1310 \\
Infrastructure \& Site Works & 41200 \\
Subtotal & \\
Indirect Costs & 30 \\
Commissioning & 350 \\
Compensations & 4500 \\
Resettlement & 350 \\
Environmental Protection & 5230 \\
Subtotal & \\
Allowances & 5932 \\
Contingency (12\%) & 5932 \\
Subtotal & $\mathbf{5 5 3 6 2}$ \\
Total Capital Cost & \\
\hline
\end{tabular}

Table 3. Summary of operating cost estimates

\begin{tabular}{lcc}
\hline Costs Centre & Cost/t of Ore (US\$) & Annual Cost (US\$ x 10 \\
\hline Mining & & \\
Equipment & 5.260 & 5681 \\
Grade Control & 1.400 & 1512 \\
Supervision and Labour & 1.221 & 1319 \\
Motor Vehicles & 0.083 & 90 \\
Subtotal & 7.964 & 8602 \\
Treatment & & 4028 \\
Reagents and Consumable & 3.730 & 444 \\
Power & 0.411 & 618 \\
Labour and Supervision & 0.572 & 1522 \\
Maintenance, Assaying and Vehicles & 1.409 & 6612 \\
Subtotal & 6.122 & 1474 \\
Overheads & & 115 \\
Supervision & 1.365 & 120 \\
Vehicles & 0.106 & 100 \\
Mine Office & 0.111 & 1809 \\
Miscellaneous & 0.093 & 2043 \\
Subtotal & 1.675 & $\mathbf{1 9 0 6 6}$ \\
Contingency (12\%) & 1.892 & \\
Total Operating Cost & $\mathbf{1 3 . 2 5 3}$ & \\
& & \\
\hline
\end{tabular}

(i) Total capital investment $=\$ 55362000$

(ii) Annual operating cost $=\$ 19066000 / \mathrm{yr}$

(iii) Annual production $=1080000 \mathrm{t} / \mathrm{yr}$

(iv) Gold price $=\$ 32.15 / \mathrm{g}(\$ 1000 / \mathrm{oz})$

(v) Mill head grade $=2.4 \mathrm{~g} / \mathrm{t}$

(vi) Recovery $=80 \%$

(vii) Ore dilution $=10 \%$

(viii) Ore loss $=10 \%$ 
(ix) Project life $=9$ yrs

(x) Interest on loan capital $=12 \%$

(xi) Discount rate $=20 \%$

(xii) Capital structure $=60 \%$ equity and $40 \%$ loan

(xiii) Working capital $=20 \%$ of annual operating cost

\section{Results and Discussion}

\subsection{Economic Evaluation of the SGM Project under PNDCL 153}

Table 4 presents the result of the cash flow analysis of the Sikaman Gold Mining Project under the PNDCL 153 regime. Since the NPV of $\$ 48205020$ is greater than zero and the IRR of $68.71 \%$ is greater than the minimum rate of return of 20\%, the Sikaman Gold Mining Project is adjudged to be economically viable under the PNDCL 153 fiscal policy regime.

Figure 3 presents the sensitivity analysis conducted by varying the revenue, operating cost and capital cost. The result indicates that the Sikaman Gold Mining Project will continue to be viable until the revenue decreases beyond $40 \%$ of the base case value. The project is not sensitive to capital and operating costs within the variation of $\pm 60 \%$.

Figure 4 represents the risk profiles which show the distribution of the variables as normal with the probability that $\mathrm{NPV}$ is less or equal to zero to be $9 \%$. The project is said to be economically viable with an associated risk of $9 \%$.

\subsection{Evaluation of the SGM Project under Act 703}

Table 5 presents the result of the cash flow analysis of the Sikaman Gold Mining Project under the Act 703 regime. Since the NPV of $\$ 91501690$ is greater than zero and the IRR of $97.10 \%$ is greater than the minimum rate of return of 20\%, the Sikaman Gold Mining Project is adjudged to be economically viable under the Act 703 fiscal policy regime.

Figure 5 presents the sensitivity analysis conducted by varying the revenue, operating cost and capital cost. The result indicates that the Sikaman Gold Mining Project will continue to be viable until the revenue decreases beyond $47 \%$ of the base case value. The project is not sensitive to the capital cost and operating cost within the variation of $\pm 60 \%$.

Figure 6 represents the risk profiles which show the distribution of the variables as normal with the probability that NPV is less or equal to zero to be 5\%. The project is said to be economically viable with an associated risk of 5\%.

\subsection{Evaluation of the SGM Project under the Current Regime}

Table 6 presents the result of the cash flow analysis of the Sikaman Gold Mining Project under the current regime. Since the NPV of $\$ 77238570$ is greater than zero and the IRR of $80.33 \%$ is greater than the minimum rate of return of $20 \%$, the Sikaman Gold Mining Project is adjudged to be viable under the current fiscal policy framework.

Figure 7 presents the sensitivity analysis conducted by varying the revenue, operating cost and capital cost. The result indicates that the Sikaman Gold Mining Project will continue to be viable until the revenue decreases beyond $46 \%$ of the base case value. The project is not sensitive to the capital cost and operating cost within the variation of $\pm 60 \%$.

Figure 8 represents the risk profiles which show the distribution of the variables as normal with the probability that $\mathrm{NPV}$ is less or equal to zero to be $6 \%$. The project is said to be economically viable with an associated risk of $6 \%$.

Table 4. Results of cash flow analysis of the SGM project under PNDL 153

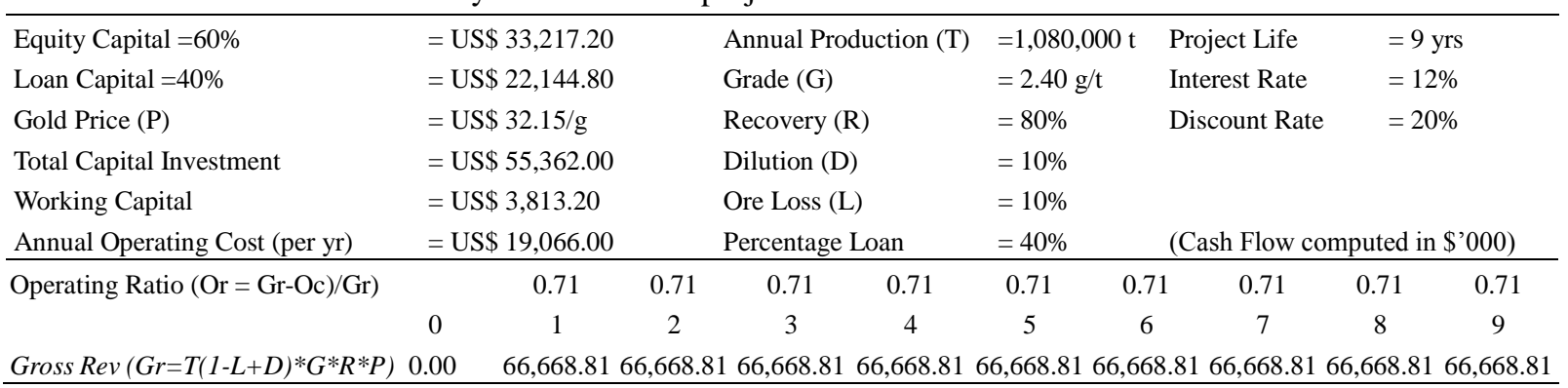


Less:

Royalty $(3-12 \%, 30 \%>$ Or $>70 \%)$ Annual Operating Cost (per yr)

Net Revenue (Rn)

Less:

Inv Allowance (5\% 1st yr only)

Cap Allowance (75\%; then 50\%)

Interest

Loss Carry Forward

Taxable Income (Ti)

Less:

Tax, $\mathrm{T}=(35 \%$ of $\mathrm{Ti})$

Net Income

Add:

Inv Allowance (5\% 1st yr only)

Cap Allowance (75\%; then 50\%)

Loss Carry Forward

Working Capital (Last yr only)

Less:

Loan Principal Repayment

Equity Capital

Working Capital (first yr only)

Additional Profit Tax (25\%)

CASH FLOW (CF)

NPV @ 20\%=\$48,205.02

IRR $=68.71 \%$

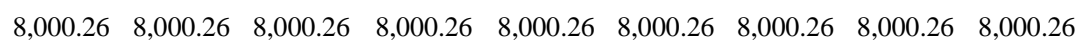
$\begin{array}{lllllllllllll}19,066.00 & 19,066.00 & 19,066.00 & 19,066.00 & 19,066.00 & 19,066.00 & 19,066.00 & 19,066.00 & 19,066.00\end{array}$

$0.00 \quad 39,602.5539,602.5539,602.55 \quad 39,602.55 \quad 39,602.5539,602.5539,602.5539,602.55 \quad 39,602.55$

$\begin{array}{llllllllll}0.00 & 2,768.10 & 0.00 & 0.00 & 0.00 & 0.00 & 0.00 & 0.00 & 0.00 & 0.00\end{array}$

$\begin{array}{llllllllll}0.00 & 41,521.50 & 5,536.20 & 2,768.10 & 1,384.05 & 692.02 & 346.01 & 173.01 & 86.50 & 43.25\end{array}$

$\begin{array}{llllllllll}0.00 & 2,657.38 & 2,362.11 & 2,066.85 & 1,771.58 & 1,476.32 & 1,181.06 & 885.79 & 590.53 & 295.26\end{array}$

$\begin{array}{llllllllll}0.00 & 0.00 & 7,344.42 & 0.00 & 0.00 & 0.00 & 0.00 & 0.00 & 0.00 & 0.00\end{array}$

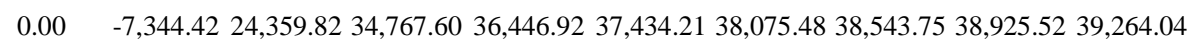

$\begin{array}{lllllllllllll}0.00 & 0.00 & 8,525.94 & 12,168.66 & 12,756.42 & 13,101.97 & 13,326.42 & 13,490.31 & 13,623.93 & 13,742.41\end{array}$

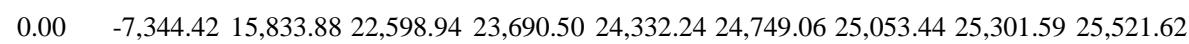

$\begin{array}{cccccccccc}0.00 & 2,768.10 & 0.00 & 0.00 & 0.00 & 0.00 & 0.00 & 0.00 & 0.00 & 0.00 \\ 0.00 & 41,521.50 & 5,536.20 & 2,768.10 & 1,384.05 & 692.02 & 346.01 & 173.01 & 86.50 & 43.25 \\ 0.00 & 0.00 & 7,344.42 & 0.00 & 0.00 & 0.00 & 0.00 & 0.00 & 0.00 & 0.00 \\ 0.00 & 0.00 & 0.00 & 0.00 & 0.00 & 0.00 & 0.00 & 0.00 & 0.00 & 3,813.20\end{array}$

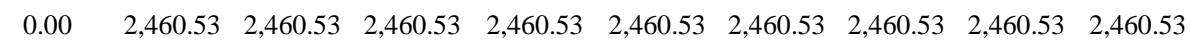

$\begin{array}{llllllllll}33,217.20 & 0.00 & 0.00 & 0.00 & 0.00 & 0.00 & 0.00 & 0.00 & 0.00 & 0.00\end{array}$

$\begin{array}{llllllllll}0.00 & 3,813.20 & 0.00 & 0.00 & 0.00 & 0.00 & 0.00 & 0.00 & 0.00 & 0.00\end{array}$

$\begin{array}{llllllllll}0.00 & 0.00 & 7,154.02 & 6,243.34 & 6,096.40 & 6,010.01 & 5,953.90 & 5,912.93 & 5,879.52 & 5,849.90\end{array}$

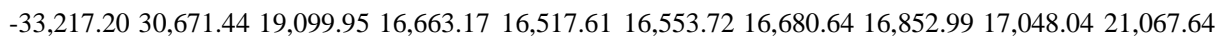

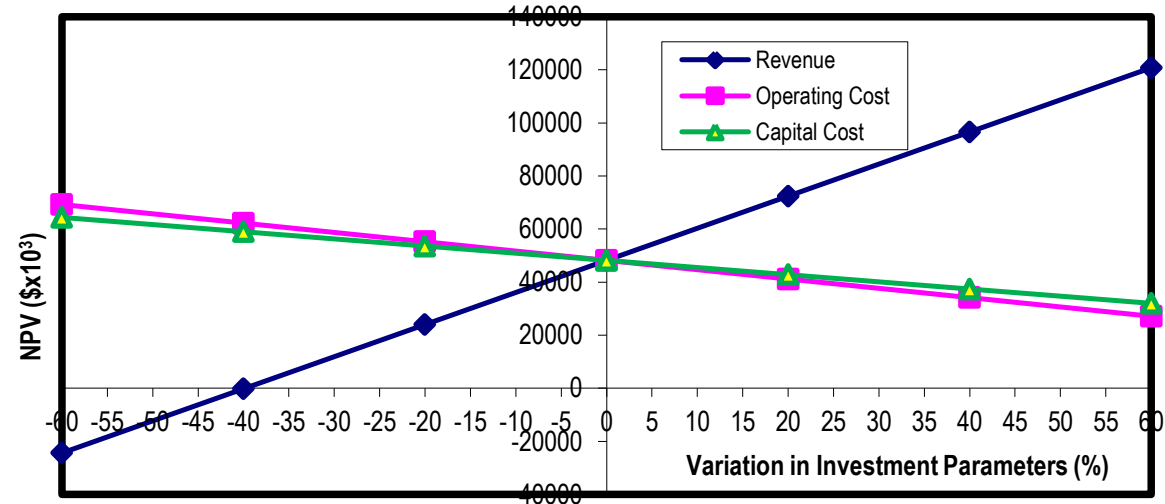

Figure 3. NPV vrs variation in investment parameters of the SGM project under PNDCL 153

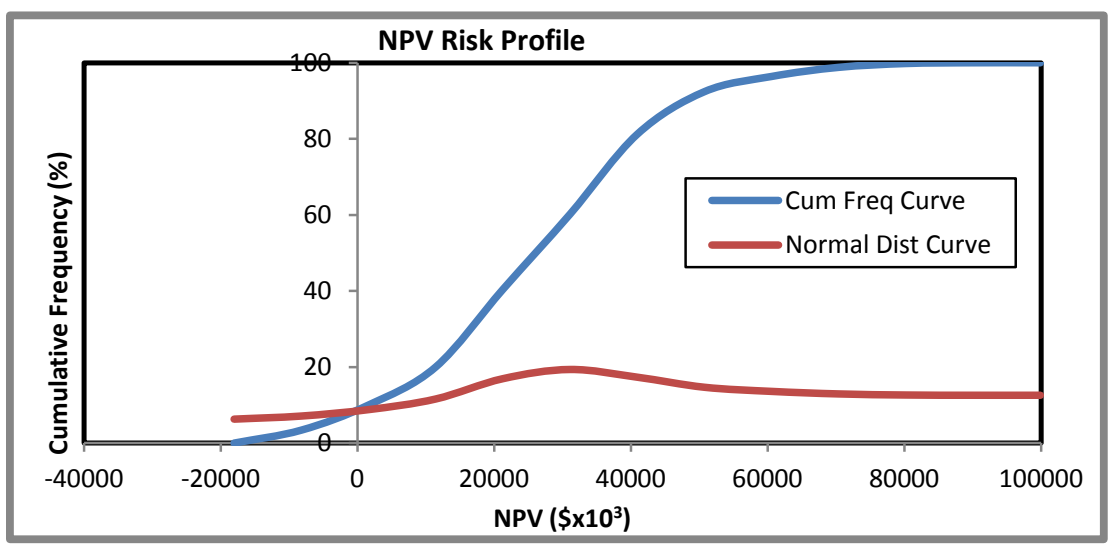

Figure 4. Risk profiles of NPV for SGM project under PNDC law 153 
Table 5. Results of cash flow analysis of the SGM project under Act 703

\begin{tabular}{|c|c|c|c|c|c|}
\hline Equity Capital $=60 \%$ & $=$ US $\$ 33,217.20$ & Annual Production (T) & $=1,080,000 \mathrm{t}$ & \multicolumn{2}{|l|}{ Project Life $=9$ yrs } \\
\hline Loan Capital $=40 \%$ & $=$ US $\$ 22,144.80$ & Grade $(\mathrm{G})$ & $=2.40 \mathrm{~g} / \mathrm{t}$ & \multicolumn{2}{|l|}{ Interest Rate $=12 \%$} \\
\hline Gold Price $(\mathrm{P})$ & $=\mathrm{US} \$ 32.15 / \mathrm{g}$ & Recovery (R) & $=80 \%$ & \multicolumn{2}{|l|}{ Discount Rate $=20 \%$} \\
\hline Total Capital Inv. & $=$ US $\$ 55,362.00$ & Dilution (D) & $=10 \%$ & & \\
\hline Working Capital & $=\mathrm{US} \$ 3,813.20$ & Ore Loss (L) & $=10 \%$ & & \\
\hline Operating Cost (per yr) & $=\mathrm{US} \$ 19,066.00$ & Percentage Loan & $=40 \%$ & \multicolumn{2}{|c|}{ (Cash Flow computed in $\left.\${ }^{\prime} 000\right)$} \\
\hline \multirow[t]{2}{*}{ Operating Ratio $(\mathrm{Or}=\mathrm{Gr}-\mathrm{Oc}) / \mathrm{Gr})$} & 0.71 & 0.71 & 0.71 & 0.71 & 0.71 \\
\hline & 2 & 4 & 6 & 7 & 9 \\
\hline
\end{tabular}

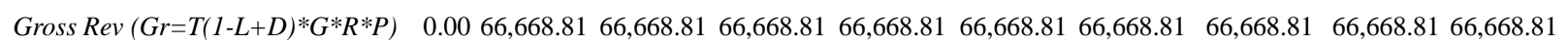
Less:

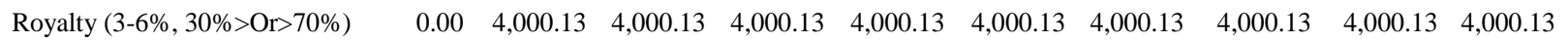

Operating Cost (per yr)

Net Revenue (Rn)

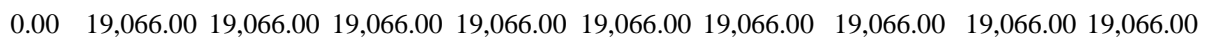

Less:

Inv Allow. (5\% 1st yr only)

Cap Allow. (75\%; then 50\%)

Interest

Loss Carry Forward

Taxable Income (Ti)

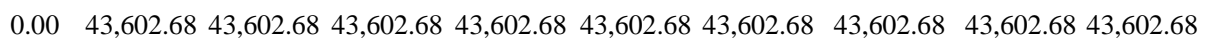

Less:

Tax, $\mathrm{T}=(35 \%$ of $\mathrm{Ti})$

Net Income

Add:

Inv Allow. (5\% 1st yr only)

Cap Allow.e (75\%; then 50\%)

Loss Carry Forward

$\begin{array}{llllllllll}0.00 & 2,768.10 & 0.00 & 0.00 & 0.00 & 0.00 & 0.00 & 0.00 & 0.00 & 0.00\end{array}$

$\begin{array}{llllllllll}0.00 & 41,521.50 & 5,536.20 & 2,768.10 & 1,384.05 & 692.02 & 346.01 & 173.01 & 86.50 & 43.25\end{array}$

$\begin{array}{cccccccccc}0.00 & 2,657.38 & 2,362.11 & 2,066.85 & 1,771.58 & 1,476.32 & 1,181.06 & 885.79 & 590.53 & 295.26\end{array}$

$\begin{array}{llllllllll}0.00 & 0.00 & 3,344.29 & 0.00 & 0.00 & 0.00 & 0.00 & 0.00 & 0.00 & 0.00\end{array}$

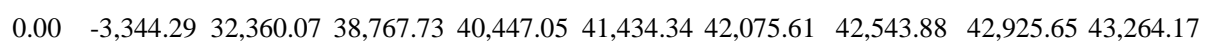

Working Capital (Last yr only)

Less:

Loan Principal Repayment

Equity Capital

Working Capital (first yr only)

Additional Profit Tax (25\%)

CASH FLOW (CF)

NPV @ 20\% = 91,501.69

IRR $=\mathbf{9 7 . 1 0 \%}$

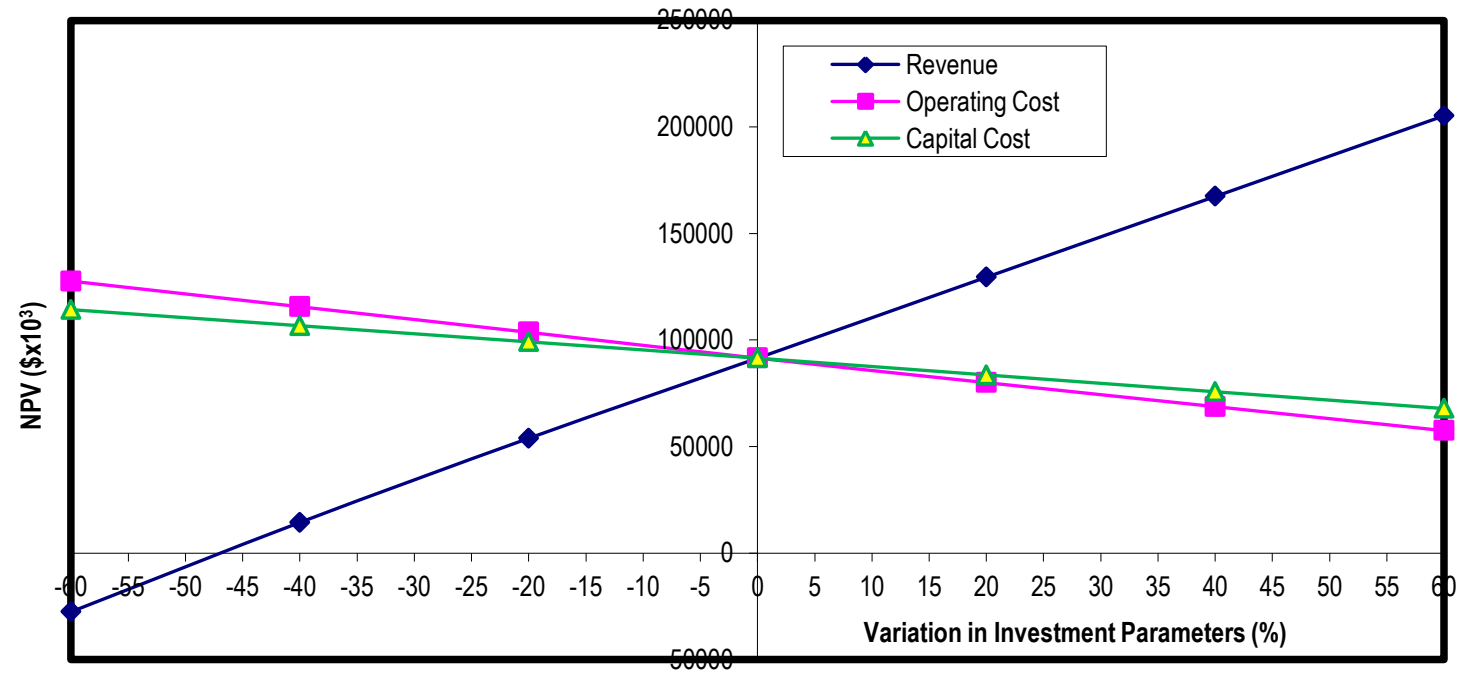

Figure 5. NPV vrs variation in investment parameters of the SGM project under Act 703 


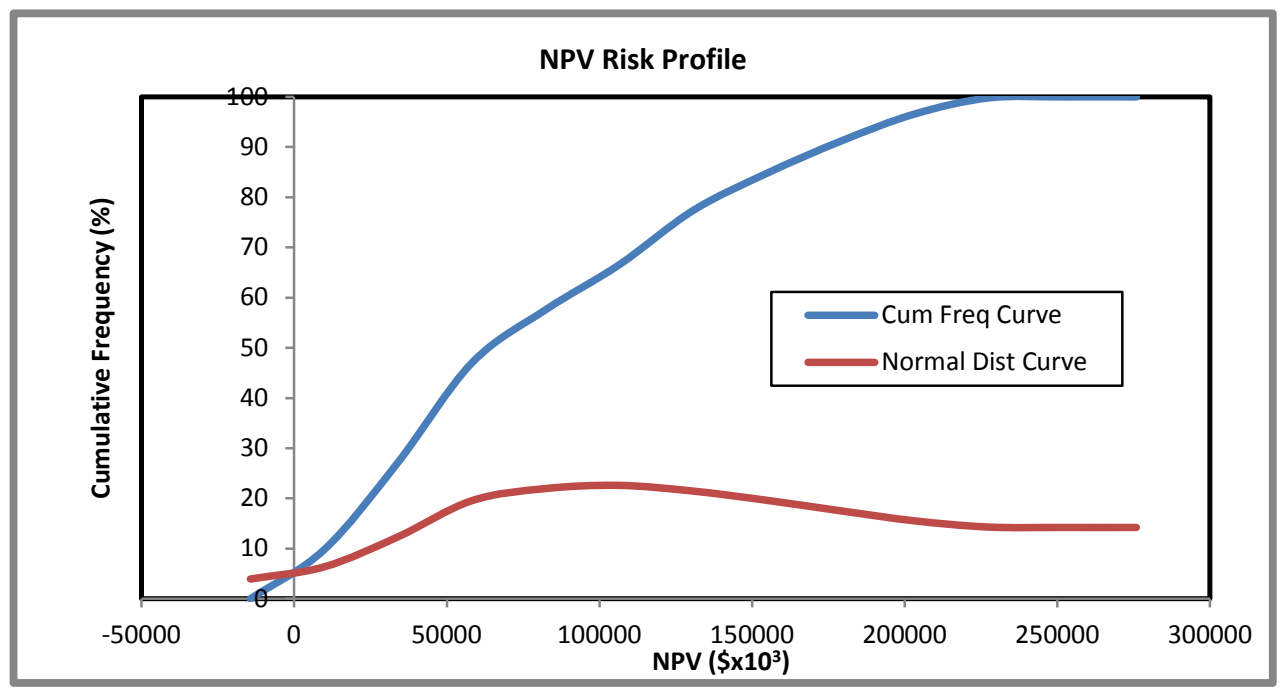

Figure 6. Risk profiles of NPV for SGM project under Act 703

Table 6. Results of cash flow analysis of the SGM project under current regime

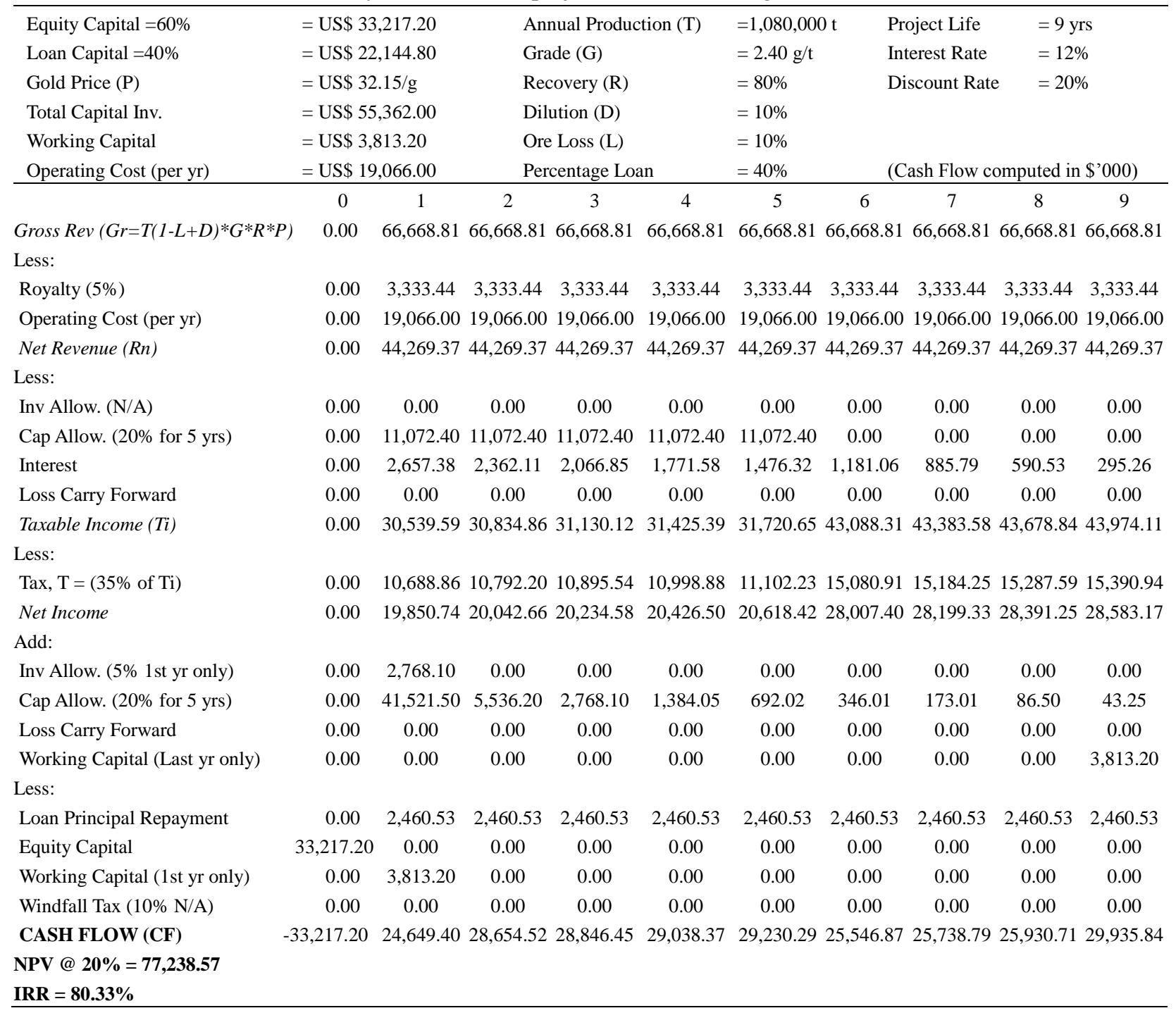




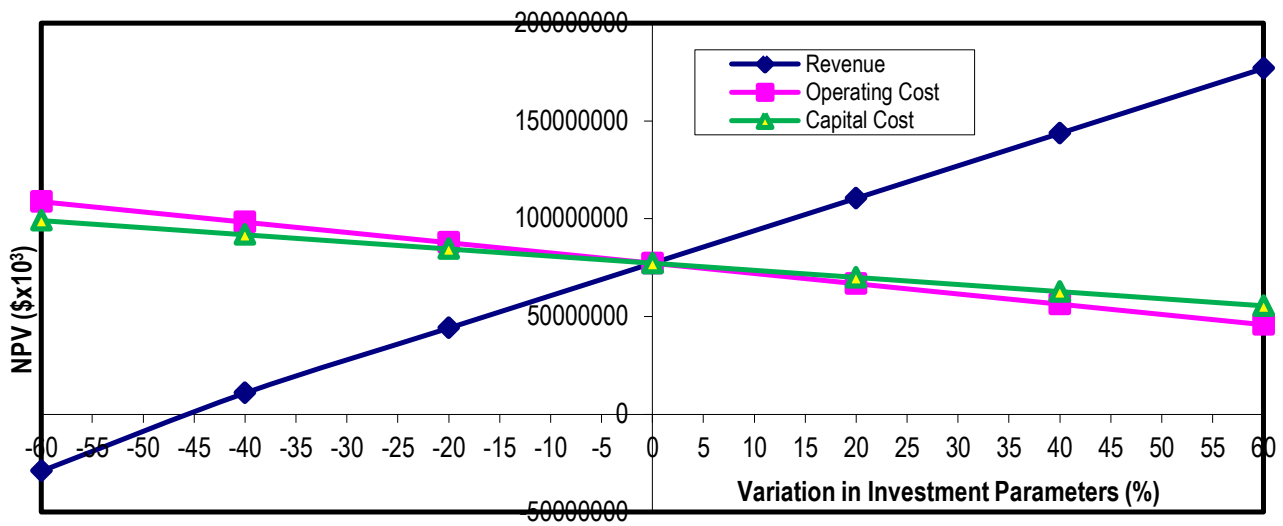

Figure 7. NPV vrs variation in investment parameters of the SGM project under current fiscal regime

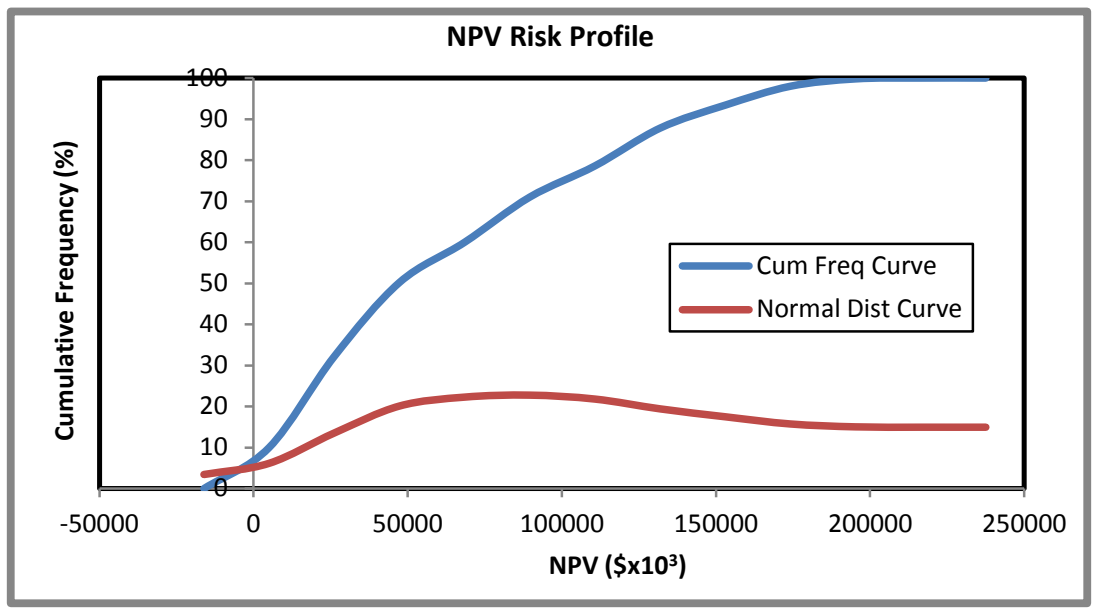

Figure 8. Risk profiles of NPV for SGM project under current fiscal regime

\subsection{Comparative Analysis}

Figure 9 shows the summary results of the cash flow and risk analyses of the Sikaman Gold Mining Project under the three policy regimes under consideration. It can be deduced that the Sikaman Gold Mining Project is most viable with least risk under the Mineral and Mining Act 2006 (Act 703) followed by the current policy regime.

It could be observed that some of the contributing factors that made Act 703 the most economically favourable are the reduced corporate tax of $25 \%$ instead of $35 \%$, the lower royalty rate of $3 \%-6 \%$, and the scrapping of the additional profit tax.

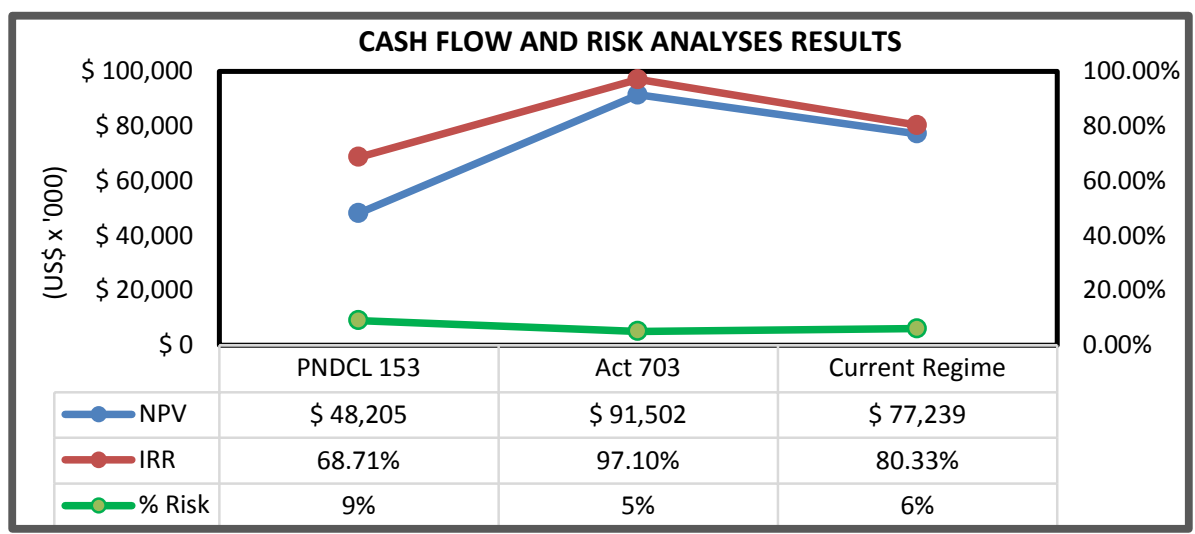

Figure 9. Summary results of cash flow and risk analyses of the SGM project under the three fiscal policy Regimes 


\section{Conclusions and Recommendations}

The paper has studied the fiscal regimes that govern the economic evaluation of mineral projects within the Ghanaian investment climate. Three distinctions were made: fiscal policies that revitalized the mineral industry from 1986 with the enactment of the PNDCL 153 and its minor amendments; major amendment of the PNDCL 153 which gave way to the Minerals and Mining Act 2006, Act 703; and the current amendments of Act 703 in 2010, 2012 and 2015.

Economic analysis of the Sikaman Gold Mining Project under the three policy regimes revealed that the project is economically viable under the three regimes as the NPVs and IRRs were greater than zero and the minimum rate of return of $20 \%$ respectively.

Sensitivity analysis revealed that the project is most sensitive under the PNDCL 153 as the project ceases to be viable should the revenue decrease below $40 \%$ against $46 \%$ under the current policy regime and the least sensitive value of $47 \%$ under Act 703. In all the three regimes, the project was not sensitive to capital and operating costs within the variation of $\pm 60 \%$ of the base case values.

Risk analysis conducted indicated that the probability of failure was highest under the PNDCL 153 (9\%) and least under Act 703 (5\%) with the current regime falling in-between (6\%).

It could therefore be concluded from this study that the government was justified for amending its fiscal mineral policies to reflect modern trend in the mineral sector especially in the face of high gold prices and high production to maximise returns from the mineral industry.

It is recommended that the government should discuss such amendments with stakeholders especially the Chamber of Mines so as not to send wrong signal of being hostile to investors. Furthermore, taxes should be diversified to cover environmental remediation and corporate social responsibilities for the local mining communities instead of concentrating on corporate tax. Finally, mineral investors are encouraged to explore the stability and development agreements in order to stabilize their investments from fiscal policy changes.

The import of this research was to make an academic contribution to the dissenting views that the public hold for the latest changes in the mineral policies in Ghana. A limitation of this research could be the adoption of the traditional method of evaluating mineral projects which encompass discounted cash flow analysis, sensitivity analysis and risk analysis using Monte Carlo simulation technique instead of more advanced technique such as real options analysis. This is to make the results easily understandable to end-users as these are the prevailing techniques for economic evaluation of mineral projects in Ghana.

Future research could consider comparing the current fiscal regime of Ghana with those of the competing countries within the Sub-Saharan African region to assess whether Ghana could continue to pride itself as a preferred investment destination within the sub-region.

\section{References}

Agbesi, Y. P. (2007). The two sides of Ghana's gold boom: a case study of Wassa West District. The Oguaa Journal of Social Science, 4, 1-6.

Akabzaa, T., \& Darimani, A. (2001). Impact of mining sector investment in Ghana: A study of the Tarkwa Mining Region. Draft Report Prepared for SAPRI, 7-26.

Ampofo, K. D. (2017). Reasons why Real Options Analysis (ROA) is not widely adopted in the mineral industry (p. 180). PhD Thesis, The University of Queensland, Australia. https://doi.org/10.14264/uql.2017.622

Amponsah-Tawiah, K., \& Dartey-Baah, K. (2011). The mining industry in Ghana: A blessing or a curse. International Journal of Business and Social Science, 2(12), 62-69. Retrieved from http://ijbssnet.com/journals/Vol._2_No._12\%3B_July_2011/8.pdf

Andrews-Speed, P., \& Rogers, C. D. (1999). Mining taxation issues for the future. Resources Policy, 25(4), 221-227. https://doi.org/10.1016/S0301-4207(99)00029-X

Antwi-Boasiako, A. (2003). Proliferation of surface mining in Ghana: A threat or a blessing to the poor in the mining areas in Ghana: A study of Tarkwa mining area (p. 12). Unpublished MSc Thesis, University of Lund, Sweden. Retrieved from http://www.lumes.lu.se/html/batch_6

Appiah, D. O., \& Buaben, J. N. (2012). Is gold mining a bane or a blessing in sub-Saharan Africa: The case of Ghana. International Journal of Development and Sustainability, 1(3), 1033-1048.

Aryee, B. N. A. (2001). Ghana's mining sector: It's contribution to national economy. Resource Policy, 27(2), 61-75. https://doi.org/10.1016/S0301-4207(00)00042-8 
Aryee, B. N. A. (2012). Contribution of the minerals and mining sector to national development: Ghana's experiment. GREAT Insights, 1(5). Maastricht: ECDPM. Retrieved from http://ecdpm.org/great-insights/extractive-sector-for-development/contribution-minerals-mining-sector-nati onal-development-ghan as-experiment/

Awudi, G. B. K. (2002). The role of foreign direct investment (FDI) in the mining sector of Ghana and the environment. Conference on Foreign Direct Investment and the Environment, OECD, Paris. Retrieved from http://www.oecd.org/countries/ghana/1819492.pdf

Banson, A. K., \& Eshun, P. A. (2010). Economic evaluation of small scale salt mining projects in Ghana - A case study. Proceedings of the First Biennial UMaT International Conference on Mining and Mineral Processing (pp. 487-502), Expanding the Frontiers of Mining Technology, Tarkwa, Ghana, $4^{\text {th }}-7^{\text {th }}$ August, 2010.

Bhappu, R. R., \& Guzman, J. (1995). Mineral investment decision making. Engineering and Mining Journal,. 36-38.

Clark, N. L. (1994). A country study: Ghana. In La V. Berry (Ed.), Library of Congress Federal Research Division (p. 168). Retrieved from https://archive.org/stream/ghanacountrystud00berr_0/ghanacountrystud00 berr_0_djvu.txt

Cobblah, A. (2005). Feasibility report of the Obuoho ore and Bondaye tailings deposit at Prestea in the Western Region of Ghana. Final report prepared for Prestea Sankofa Gold Limited, Prestea (Unpublished).

Eshun, P. A., \& Mireku-Gyimah, D. (2004). Accounting for risks in economic evaluation of gold mining projects in Ghana - A case study, Mining North, Edmonton 2004. CIM Mining Industry Conference and Exhibition, Alberta, Canada.

Focus Economics. (2018). Gold: the most precious of metals (Part 3). Retrieved from https://www.focus-economics.com/blog/gold-the-most-precious-of-metals-part-3

Gbireh, A. B., Cobblah, A., \& Suglo, R. S. (2007). Analysis of the trends of gold mining in Ghana. Ghana Mining Journal, 9, 38-49.

Hinde, C. (2010). Ghana, Mining Journal Special Publication. Aspermont UK. Retrieved from http://www.mining-journal.com/_data/assets/supplement_file_attachment/0008/205892/Ghana_scr.pdf

Kesse, G. O. (1985). The Mineral and Rock Resources of Ghana. A. A. Balkema, Rotterdam, the Netherlands, p. 610.

Liu, S. (2012). GMWU urges Government to stay firm on the proposed windfall tax. Ghanaweb. Retrieved from https://www.ghanaweb.com/GhanaHomePage/NewsArchive/GMWU-urges-Government-to-stay-firm-on-th e-proposed-windfall-tax-249877

Mirakovski, D., Krstev, B., Krstev, A., \& Petrovski, F. (2009). Mine project evaluation techniques. Natural Resources and Technologies, 3(3). Retrieved from http://eprints.ugd.edu.mk/3735/1/MINE\% 20PROJECT \%20EVALUATION\%20TECHNIQUES.pdf

Mireku-Gyimah, D., \& Darko, J. O. (1996). Economic risk analysis of mineral projects in Ghana - A simulation approach. Surface Mining 1996 (pp. 71-75). South African Institute of Mining and Metallurgy, Johannesburg.

Mireku-Gyimah, D., \& Owusu Ansah, N. K. (2017). An economic evaluation of the Loye Quarry of Atiwa Quarries Limited. Ghana Mining Journal, 17(1), 43-53.

Smith, K. A. (2015). Assessing the effects of taxation on the mining industry (A case study of AngloGold Ashanti, Iduapriem Mines). MBA (Finance) Thesis, Kwame Nkrumah University of Science and Technology, Kumasi.

Songhai Advisory, (2011, December 01). Ghana's mining sector: increase in taxes spark opposition from sector. African Argument. Retrieved from http://africanarguments.org/2011/12/01/ghanas-mining-sector-increase-in-corporate-and-windfall-tax-by-so nghai-advisory/

Songsore, J., Yankson, P. W. K., \& Tsikata, G. K. (1994). Mining and the environment: towards a win-win strategy. A study of the Tarkwa-Aboso-Nsuta mining complex. Final report prepared for the Ministry of Environment, Science and Technology (MEST-EPC) and the World Bank in support of the formulation of a growth strategy for the Western Region of Ghana.

Tsikata, F. S. (1997). The vicissitudes of mineral policy in Ghana. Resource Policy, 23(1-2), 9-14. https://doi.org/10.1016/S0301-4207(97)00006-8 
World Gold Council. (2017). Gold Price. Retrieved from https://www.gold.org/data/gold-price

Yirenkyi, S. (2008). Surface mining and its socio-economic impacts and challenges. Surface Mining 2008 (pp. 181-202). The Southern African Institute of Mining and Metallurgy.

\section{Copyrights}

Copyright for this article is retained by the author(s), with first publication rights granted to the journal.

This is an open-access article distributed under the terms and conditions of the Creative Commons Attribution license (http://creativecommons.org/licenses/by/4.0/). 